\title{
Assessment of Target Volume Definition for Irradiation of Hemangiopericytomas: An Original Article
}

\author{
Omer Sager*, Selcuk Demiral, Ferrat Dincoglan and Murat Beyzadeoglu \\ Department of Radiation Oncology; University of Health Sciences, Gulhane Medical Faculty, Ankara, Turkey
}

Submission: September 30, 2020; Published: November 06, 2020

*Corresponding author: Dr. Omer Sager, University of Health Sciences, Gulhane Medical Faculty, Department of Radiation Oncology, Gn.Tevfik Saglam Cad. 06018, Etlik, Kecioren, Ankara, Turkey

\begin{abstract}
Background: Hemangiopericytomas arise from the mesenchymal cells with pericytic differentiation. Clinical course of these rare tumors may be aggressive with high propensity for local recurrence and metastases. Radical resection is the treatment of choice for lesions amenable to surgery. Nevertheless, radiation therapy (RT) may have a role in management of hemangiopericytomas either as an adjunctive, salvage or primary treatment, or for palliation of metastases in selected patients. Target volume definition is a critical aspect of RT.
\end{abstract}

Objective: Aim of this study is to assess incorporation of multimodality imaging with magnetic resonance imaging (MRI) into target volume definition for irradiation of hemangiopericytomas.

Methods: In this study, treatment volume definition with multimodality imaging by incorporating MRI or by use of computed tomography (CT)-simulation images only was comparatively evaluated for patients with hemangiopericytoma.

Results: Ground truth target volume defined by the board-certified radiation oncologists following meticulous evaluation, colleague peer review, collaboration, and ultimate consensus was found to be identical with target determination based on CT-MR fusion based imaging in this study.

Conclusion: Accurate target volume determination is an indispensable part of RT for management of hemangiopericytomas. Incorporation of MRI in the target volume definition process may be considered for optimization of treatment volume designation for successful RT applications. Clearly, future studies are required to shed light on this issue.

Keywords: Hemangiopericytoma; Target Volume Definition; Magnetic Resonance Imaging (MRI)

\section{Introduction}

Hemangiopericytomas, firstly described by Stout and Murray in 1942, are solitary fibrous tumors arising from the mesenchymal cells with pericytic differentiation [1]. Clinical course of these rare tumors may be aggressive with high propensity for local recurrence and metastases [2,3]. Radical resection is the treatment of choice for lesions amenable to surgery [4]. Nevertheless, radiation therapy (RT) may have a role in management of hemangiopericytomas either as an adjunctive, salvage or primary treatment or for palliation of metastases in selected patients. Irradiation with conventionally fractionated RT (CFRT) or radiosurgery as Stereotactic Radiosurgery (SRS), Fractionated Stereotactic Radiation Therapy (FSRT), and Stereotactic Body Radiation Therapy (SBRT) or
Stereotactic Ablative Body Radiotherapy (SABR) can be utilized for management of numerous central nervous system (CNS) disorders and for several other malign and benign tumors throughout the human body with encouraging outcomes [5-26]. In the context of hemangioperycytomas, the role of irradiation has been investigated [27-29]. Although there has been controversy regarding the radiation dose and the role of adjuvant irradiation, several series report reasonable rates of local control with low toxicity particularly by use of stereotactic irradiation [30-34]. As the importance of target definition becomes more critical in stereotactic irradiation regimens with high fraction doses, incorporation of multimodality imaging for optimal treatment volume determination is judiciously utilized. Within this context, 


\section{Cancer Therapy \& Oncology International Journal}

we assessed the incorporation of multimodality imaging with magnetic resonance imaging (MRI) into target volume definition for irradiation of hemangiopericytomas in this study.

\section{Materials and Methods}

Treatment volume definition with multimodality imaging by incorporating MRI or by use of computed tomography (CT)simulation images only was comparatively evaluated for patients with hemangiopericytoma in this study. Ground truth target volume which was used as the reference for actual treatment and comparison purposes was defined by the board-certified radiation oncologists after meticulous assessment, collaboration, colleague peer review, and ultimate consensus. Thorough evaluation was performed regarding the lesion size, lesion localization, symptomatology and patient preferences along with predicted results of treatment on an individual basis. Radiation treatment simulation for RT planning was performed at the CTsimulator (GE Lightspeed RT, GE Healthcare, Chalfont St. Giles, UK) available at our tertiary cancer center. Planning CT images were acquired and sent to the delineation workstation (SimMD, GE, UK) for outlining of treatment volumes and critical organs. Either CT-simulation images only or fused CT and MR images were utilized for target volume definition for RT. Treatment volume definition with CT only and by incorporation of CT-MR fusion was evaluated with comparative assessment. Definition of the ground truth target volume was performed by the boardcertified radiation oncologists following meticulous assessment, collaboration, thorough evaluation, colleague peer review and ultimate consensus for use in actual treatment as well as for the purpose of comparative analysis. Treatments were delivered with the Synergy (Elekta, UK) linear accelerator (LINAC) by use of Image Guided Radiation Therapy (IGRT) techniques.

\section{Results}

The available treatment planning systems at our tertiary cancer center were used for radiation treatment planning. Priority was given for target coverage with optimal sparing of normal tissues. Synergy (Elekta, UK) LINAC was used for RT administration. Irradiation treatment volume definition by CTonly imaging and by CT-MR fusion based imaging was assessed comparatively. Ground truth target volume defined by the boardcertified radiation oncologists following meticulous evaluation, colleague peer review, collaboration, and ultimate consensus was found to be identical with target determination based on CT-MR fusion based imaging in this study.

\section{Discussion}

Hemangiopericytomas are rare but aggressive tumors with high tendency for local recurrence and metastasis. RT has been utilized for improving local control rates and for palliation of metastases. There have been significant advances in the discipline of radiation oncology with introduction of adaptive irradiation strategies and state of the art treatment delivery techniques including incorporation of automatic segmentation procedures, molecular imaging, Image Guided Radiation Therapy (IGRT), Adaptive Radiation Therapy (ART), Intensity Modulated Radiation Therapy (IMRT), Breathing Adapted Radiation Therapy (BART), and stereotactic irradiation with SRS, HFSRT, and SBRT [35-45]. Advanced irradiation techniques such as SRS offer improved precision and promising therapeutic oucomes, however, delivery of high doses in a single or a few fractions require accurate target definition. Accurate definition of RT treatment volumes is an indispensable part of irradiation for hemangiopericytomas. Avoidance of geographical misses and excessive RT toxicity are critical aspects of radiotherapeutic management. While outlining of larger RT treatment volumes can result in excessive radiation induced toxicity, determination of smaller than actual treatment volumes can lead to geopraphical misses with consequent disease progression. In this context, incorporation of multimodality imaging can be used for improving the precision of target localization, and integrated use of fused CT and MR images can facilitate optimization of treatment volume designation for successful RT applications. Indeed, several studies addressed the utility of multmodality imaging for RT target definition [4663]. Our study may add to the literature given the limited data regarding the utility of multimodality imaging based target definition for irradiation of hemangiopericytomas.

\section{Conclusion}

In conclusion, accurate target volume determination is an indispensable part of RT for management of hemangiopericytomas. Incorporation of MRI in the target volume definition process may be considered for optimization of treatment volume designation for successful RT applications. Clearly, future studies are required to shed light on this issue.

\section{Conflict of Interest \& Acknowledgement}

There are no conflicts of interest and no acknowledgements.

\section{References}

1. Stout AP, Murray MR (1942) Hemangiopericytoma: A Vascular Tumor Featuring Zimmermann's Pericytes. Ann Surg 116(1): 26-33.

2. Zweckberger K, Jung CS, Mueller W, Unterberg AW, Schick U (2011) Hemangiopericytomas grade II are not benign tumors. Acta Neurochir (Wien) 153(2): 385-394.

3. Reddy S, Plitt A, Raisanen J, Patel AR, Gopal P, et al. (2019) Intracranial anaplastic hemangiopericytoma presenting with simultaneous extracranial metastases: A case report and review of the literature. Surg Neurol Int 10: 148.

4. Ramakrishna R, Rostomily R, Sekhar L, Rockhill J, Ferreira M (2013) Hemangiopericytoma: Radical resection remains the cornerstone of therapy. J Clin Neurosci 21(4): 612-615.

5. Sirin S, Oysul K, Surenkok S, Sager O, Dincoglan F, et al. (2011) Linear accelerator-based stereotactic radiosurgery in recurrent glioblastoma: A single center experience. Vojnosanit Pregl 68(11): 961-966. 


\section{Cancer Therapy \& Oncology International Journal}

6. Dincoglan F, Sager O, Gamsiz H, Uysal B, Demiral S, et al. (2012) Stereotactic radiosurgery for intracranial tumors: A single center experience. Gulhane Med J 54: 190-198.

7. Dincoglan F, Beyzadeoglu M, Sager O, Oysul K, Sirin S et al. (2012) Image-guided positioning in intracranial non-invasive stereotactic radiosurgery for the treatment of brain metastasis. Tumori 98(5): 630-635.

8. Demiral S, Beyzadeoglu M, Uysal B, Oysul K, Kahya YE, et al. (2013) Evaluation of stereotactic body radiotherapy (SBRT) boost in the management of endometrial cancer. Neoplasma 60(3): 322-327.

9. Dincoglan F, Beyzadeoglu M, Sager O, Uysal B, Demiral S, et al. (2013) Evaluation of linear accelerator-based stereotactic radiosurgery in the management of meningiomas: A single center experience. J BUON 18(3): 717-722.

10. Sager 0, Beyzadeoglu M, Dincoglan F, Demiral S, Uysal B, et al. (2013) Management of vestibular schwannomas with linear accelerator-based stereotactic radiosurgery: a single center experience. Tumori 99(5): 617-622.

11. Sager O, Beyzadeoglu M, Dincoglan F, Uysal B, Gamsiz H, et al (2014) Evaluation of linear accelerator (LINAC)-based stereotactic radiosurgery (SRS) for cerebral cavernous malformations: A 15-year single-center experience. Ann Saudi Med 34(1): 54-58

12. Sager O, Beyzadeoglu M, Dincoglan F, Gamsiz H, Demiral S, et al. (2014) Evaluation of linear accelerator-based stereotactic radiosurgery in the management of glomus jugulare tumors. Tumori 100(2): 184-188.

13. Dincoglan F, Sager O, Gamsiz H, Uysal B, Demiral S, et al. (2014) Management of patients with $\geq 4$ brain metastases using stereotactic radiosurgery boost after whole brain irradiation. Tumori 100(3): 302 306.

14. Demiral S, Beyzadeoglu M, Sager O, Dincoglan F, Gamsiz H, et al. (2014) Evaluation of linear accelerator (linac)-based stereotactic radiosurgery (srs) for the treatment of craniopharyngiomas. UHOD - Uluslararasi Hematoloji-Onkoloji Dergisi 24: 123-129.

15. Gamsiz H, Beyzadeoglu M, Sager O, Dincoglan F, Demiral S, et al. (2014) Management of pulmonary oligometastases by stereotactic body radiotherapy. Tumori $100(2): 179-183$

16. Dincoglan F, Beyzadeoglu M, Sager O, Demiral S, Gamsiz H, et al. (2015) Management of patients with recurrent glioblastoma using hypofractionated stereotactic radiotherapy. Tumori 101(2): 179-184.

17. Sager O, Dincoglan F, Beyzadeoglu M (2015) Stereotactic radiosurgery of glomus jugulare tumors: Current concepts, recent advances and future perspectives. CNS Oncol 4(2): 105-114.

18. Gamsiz H, Beyzadeoglu M, Sager O, Demiral S, Dincoglan F, et al. (2015) Evaluation of stereotactic body radiation therapy in the management of adrenal metastases from non-small cell lung cancer. Tumori 101(1) 98-103.

19. Demiral S, Dincoglan F, Sager O, Gamsiz H, Uysal B, et al. (2016) Hypofractionated stereotactic radiotherapy (HFSRT) for who grade I anterior clinoid meningiomas (ACM). Jpn J Radiol 34(11): 730-737.

20. Dincoglan F, Sager 0, Demiral S, Uysal B, Gamsiz H, et al. (2017) Radiosurgery for recurrent glioblastoma: A review article. Neurol Disord Therap 1: 1-5.

21. Dincoglan F, Sager O, Demiral S, Gamsiz H, Uysal B, et al. (2019) Fractionated stereotactic radiosurgery for locally recurrent brain metastases after failed stereotactic radiosurgery. Indian J Cancer 56(2): 151-156.

22. Dincoglan F, Sager O, Uysal B, Demiral S, Gamsiz H, et al. (2019)
Evaluation of hypofractionated stereotactic radiotherapy (HFSRT) to the resection cavity after surgical resection of brain metastases: A single center experience. Indian J Cancer 56(3): 202-206.

23. Dincoglan F, Beyzadeoglu M, Sager O, Demiral S, Uysal B, et al. (2020) A Concise Review of Irradiation for Temporal Bone Chemodectomas (TBC). Arch Otolaryngol Rhinol 6: 016-020.

24. Beyzadeoglu M, Sager O, Dincoglan F, Demiral S, Uysal B, et al. (2020) Single Fraction Stereotactic Radiosurgery (SRS) versus Fractionated Stereotactic Radiotherapy (FSRT) for Vestibular Schwannoma (VS). J Surg Surgical Res 6: 062-066.

25. Sager 0, Beyzadeoglu M, Dincoglan F, Demiral S, Gamsiz H, et al. (2020) Multimodality management of cavernous sinus meningiomas with less extensive surgery followed by subsequent irradiation: Implications for an improved toxicity profile. J Surg Surgical Res 6: 056-061.

26. Krengli M, Cena T, Zilli T, Jereczek-Fossa BA, De Bari B, et al. (2020) Radiotherapy in the treatment of extracranial hemangiopericytoma/ solitary fibrous tumor: Study from the Rare Cancer Network. Radiother Oncol 144: 114-120.

27. Ciliberti MP, D’Agostino R, Gabrieli L, Nikolaou A, Sardaro A (2018) The radiation therapy options of intracranial hemangiopericytoma: An overview and update on a rare vascular mesenchymal tumor. Oncol Rev 12(2): 354.

28. Jeon SH, Park SH, Kim JW, Park CK, Paek SH, et al. (2018) Efficacy of adjuvant radiotherapy in the intracranial hemangiopericytoma. Neurooncol 137(3): 567-573.

29. Cohen-Inbar O, Lee CC, Mousavi SH, Kano H, Mathieu D, et al. (2017) Stereotactic radiosurgery for intracranial hemangiopericytomas: a multicenter study. J Neurosurg 126(3): 744-754.

30. Kim BS, Kong DS, Seol HJ, Nam DH, Lee JI (2017) Gamma knife radiosurgery for residual or recurrent intracranial hemangiopericytomas. J Clin Neurosci 35: 3541.

31. Tsugawa T, Mori Y, Kobayashi T, Hashizume C, Shibamoto Y, et al (2014) Gamma knife stereotactic radiosurgery for intracranial hemangiopericytoma. J Radiosurg SBRT 3(1): 29-35.

32. Veeravagu A, Jiang B, Patil CG, Lee M, Soltys SG, et al. (2011) CyberKnife stereotactic radiosurgery for recurrent, metastatic, and residual hemangiopericytomas. J Hematol Oncol 4: 26.

33. Kano H, Niranjan A, Kondziolka D, Flickinger JC, Lunsford LD (2008) Adjuvant stereotactic radiosurgery after resection of intracranial hemangiopericytomas. Int J Radiat Oncol Biol Phys 72: 1333-1339.

34.Sager O, Beyzadeoglu M, Dincoglan F, Oysul K, Kahya YE, et al. (2012) The Role of Active Breathing Control-Moderate Deep Inspiration Breath-Hold (ABC-mDIBH) Usage in non-Mastectomized Left-sided Breast Cancer Radiotherapy: A Dosimetric Evaluation UHOD Uluslararasi Hematoloji-Onkoloji Dergisi 22: 147-155.

35. Sager O, Beyzadeoglu M, Dincoglan F, Demiral S, Uysal B, et al. (2015) Adaptive splenic radiotherapy for symptomatic splenomegaly management in myeloproliferative disorders. Tumori 101(1): 84-90.

36. Sager O, Beyzadeoglu M, Dincoglan F, Oysul K, Kahya YE, et al. (2012) Evaluation of active breathing control-moderate deep inspiration breath-hold in definitive non-small cell lung cancer radiotherapy. Neoplasma 59(3): 333-340.

37. Sağer Ö, Dinçoğlan F, Gamsiz H, Demiral S, Uysal B, et al. (2012) Evaluation of the impact of integrated [18f]-fluoro-2-deoxy-D-glucose positron emission tomography/computed tomography imaging on staging and radiotherapy treatment volume definition of nonsmall cell lung cancer. Gulhane Med J 54: 220-227. 


\section{Cancer Therapy \& Oncology International Journal}

38. Dincoglan F, Beyzadeoglu M, Sager O, Oysul K, Kahya YE, et al. (2013) Dosimetric evaluation of critical organs at risk in mastectomized leftsided breast cancer radiotherapy using breath-hold technique. Tumori 99(1): 76-82.

39. Özsavaş EE, Telatar Z, Dirican B, Sağer Ö, Beyzadeoğlu M (2014) Automatic segmentation of anatomical structures from CT scans of thorax for RTP. Comput Math Methods Med 2014: 472890.

40. Sager O, Dincoglan F, Uysal B, Demiral S, Gamsiz H, et al. (2017) Splenic Irradiation: A Concise Review of the Literature. J App Hem Bl Tran 1(1): 101

41. Sager O, Dincoglan F, Uysal B, Demiral S, Gamsiz H, et al. (2018) Evaluation of adaptive radiotherapy (ART) by use of replanning the tumor bed boost with repeated computed tomography (CT) simulation after whole breast irradiation (WBI) for breast cancer patients having clinically evident seroma. Jpn J Radiol 36(6): 401-406.

42. Sager O, Dincoglan F, Demiral S, Uysal B, Gamsiz H, et al. (2019) Utility of Molecular Imaging with 2-Deoxy-2-[Fluorine-18] FluoroDGlucose Positron Emission Tomography (18F-FDG PET) for Small Cell Lung Cancer (SCLC): A Radiation Oncology Perspective. Curr Radiopharm 12(1): 4-10.

43. Sager O, Dincoglan F, Demiral S, Uysal B, Gamsiz H, et al. (2019) Breathing adapted radiation therapy for leukemia relapse in the breast: A case report. World J Clin Oncol 10(11): 369-374.

44. Sager 0, Dincoglan F, Demiral S, Uysal B, Gamsiz H, et al. (2020) Adaptive radiation therapy of breast cancer by repeated imaging during irradiation. World J Radiol 12(5): 68-75.

45. Demiral S, Sager O, Dincoglan F, Uysal B, Gamsiz H, et al. (2018) Evaluation of Target Volume Determination for Single Session Stereotactic Radiosurgery (SRS) of Brain Metastases. Canc Therapy \& Oncol Int J 12(5): 555848.

46. Demiral S, Dincoglan F, Sager O, Uysal B, Gamsiz H, et al. (2018) Contemporary Management of Meningiomas with Radiosurgery. Int J Radiol Imaging Technol 80: 187-190.

47. Demiral S, Sager O, Dincoglan F, Beyzadeoglu M (2019) Assessment of target definition based on Multimodality imaging for radiosurgical Management of glomus jugulare tumors (GJTs). Canc Therapy \& Oncol Int J 15(2): 555909.

48. Demiral S, Sager O, Dincoglan F, Beyzadeoglu M (2019) Assessment of Computed Tomography (CT) And Magnetic Resonance Imaging (MRI) Based Radiosurgery Treatment Planning for Pituitary Adenomas. Canc Therapy \& Oncol Int J 13(2): 555857

49. Sager O, Dincoglan F, Demiral S, Gamsiz H, Uysal B, et al. (2019) Evaluation of the Impact of Magnetic Resonance Imaging (MRI) on Gross Tumor Volume (GTV) Definition for Radiation Treatment Planning (RTP) of Inoperable High Grade Gliomas (HGGs). Concepts in Magnetic Resonance Part A 2019: 4282754.

50. Beyzadeoglu M, Sager O, Dincoglan F, Demiral S (2019) Evaluation of Target Definition for Stereotactic Reirradiation of Recurrent Glioblastoma. Arch Can Res 7(1): 3
51. Dincoglan F, Sager O, Demiral S, Beyzadeoglu M (2019) Multimodality Imaging for Radiosurgical Management of Arteriovenous Malformations. Asian Journal of Pharmacy, Nursing and Medical Sciences 7(1): 7-12.

52. Sager 0, Dincoglan F, Demiral S, Beyzadeoglu M (2019) Evaluation of Radiosurgery Target Volume Determination for Meningiomas Based on Computed Tomography (CT) And Magnetic Resonance Imaging (MRI). Cancer Sci Res Open Access 5: 1-4.

53. Sager O, Dincoglan F, Demiral S, Gamsiz H, Uysal B, et al. (2019) Utility of Magnetic Resonance Imaging (Imaging) in Target Volume Definition for Radiosurgery of Acoustic Neuromas. Int J Cancer Clin Res 6: 119.

54. Dincoglan F, Sager O, Demiral S, Beyzadeoglu M (2019) Incorporation of Multimodality Imaging in Radiosurgery Planning for Craniopharyngiomas: An Original Article. SAJ Cancer Sci 6: 103.

55. Dincoglan F, Beyzadeoglu M, Demiral S, Sager O (2020) Assessment of Treatment Volume Definition for Irradiation of Spinal Ependymomas: an Original Article. ARC Journal of Cancer Science 6(1): 1-6.

56. Dincoglan F, Demiral S, Sager O, Beyzadeoglu M (2020) Utility of Multimodality Imaging Based Target Volume Definition for Radiosurgery of Trigeminal Neuralgia: An Original Article. Biomed J Sci \& Tech Res 26: 19728-19732.

57. Sager 0, Demiral S, Dincoglan F, Beyzadeoglu M (2020) Target Volume Definition for Stereotactic Radiosurgery (SRS) Of Cerebral Cavernous Malformations (CCMs). Canc Therapy \& Oncol Int J 15: 555917.

58. Beyzadeoglu M, Dincoglan F, Sager O, Demiral S (2020) Determination of Radiosurgery Treatment Volume for Intracranial Germ Cell Tumors (GCTS). Asian Journal of Pharmacy, Nursing and Medical Sciences 8(3): $18-23$

59. Demiral S, Beyzadeoglu M, Dincoglan F, Sager O (2020) Assessment of Target Volume Definition for Radiosurgery of Atypical Meningiomas with Multimodality Imaging. Journal of Hematology and Oncology Research 3(4): 14-21.

60. Sager 0, Dincoglan F, Demiral S, Beyzadeoglu M (2020) Radiosurgery Treatment Volume Determination for Brain Lymphomas with and without Incorporation of Multimodality Imaging. Journal of Medical Pharmaceutical and Allied Sciences 9: 2398-2404.

61. Beyzadeoglu M, Dincoglan F, Demiral S, Sager O (2020) Target Volume Determination for Precise Radiation Therapy (RT) of Central Neurocytoma: An Original Article. International Journal of Research Studies in Medical and Health Sciences 5(3): 29-34.

62. Demiral S, Beyzadeoglu M, Dincoglan F, Sager O (2020) Evaluation of Radiosurgery Target Volume Definition for Tectal Gliomas with Incorporation of Magnetic Resonance Imaging (MRI): An Original Article. Biomedical Journal of Scientific \& Technical Research (BJSTR) 27: 20543-20547.

63. Sager O, Dincoglan F, Demiral S, Beyzadeoglu M (2020) Evaluation of Target Volume Determination for Irradiatıon of Pilocytic Astrocytomas: An Original Article. ARC Journal of Cancer Science 6: 1-5. 
(c) (1)

This work is licensed under Creative Commons Attribution 4.0 License

DOI:10.19080/CTOIJ.2020.17.555959
Your next submission with Juniper Publishers will reach you the below assets

- Quality Editorial service

- Swift Peer Review

- Reprints availability

- E-prints Service

- Manuscript Podcast for convenient understanding

- Global attainment for your research

- Manuscript accessibility in different formats

( Pdf, E-pub, Full Text, Audio)

- Unceasing customer service

Track the below URL for one-step submission https://juniperpublishers.com/online-submission.php 